Research, part of a Special Feature on Adaptation in Fire-Prone Landscapes: Interactions of Policies, Management. Wildfire, and Social Networks in Oregon, USA

\title{
Integrating social science into empirical models of coupled human and natural systems
}

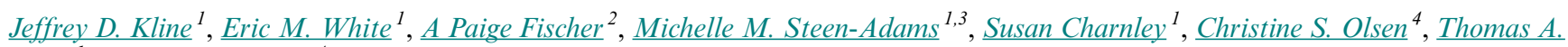 \\ Spies $^{1}$ and John D. Bailey ${ }^{4}$
}

ABSTRACT. Coupled human and natural systems (CHANS) research highlights reciprocal interactions (or feedbacks) between biophysical and socioeconomic variables to explain system dynamics and resilience. Empirical models often are used to test hypotheses and apply theory that represent human behavior. Parameterizing reciprocal interactions presents two challenges for social scientists: (1) how to represent human behavior as influenced by biophysical factors and integrate this into CHANS empirical models; (2) how to organize and function as a multidisciplinary social science team to accomplish that task. We reflect on these challenges regarding our CHANS research that investigated human adaptation to fire-prone landscapes. Our project sought to characterize the forest management activities of land managers and landowners (or "actors") and their influence on wildfire behavior and landscape outcomes by focusing on biophysical and socioeconomic feedbacks in central Oregon (USA). We used an agent-based model (ABM) to compile biophysical and social information pertaining to actor behavior, and to project future landscape conditions under alternative management scenarios. Project social scientists were tasked with identifying actors' forest management activities and biophysical and socioeconomic factors that influence them, and with developing decision rules for incorporation into the ABM to represent actor behavior. We (1) briefly summarize what we learned about actor behavior on this fire-prone landscape and how we represented it in an $\mathrm{ABM}$, and (2) more significantly, report our observations about how we organized and functioned as a diverse team of social scientists to fulfill these CHANS research tasks. We highlight several challenges we experienced, involving quantitative versus qualitative data and methods, distilling complex behavior into empirical models, varying sensitivity of biophysical models to social factors, synchronization of research tasks, and the need to substitute spatial for temporal variation in social data and models, among others. We offer recommendations that other research teams might consider when collaborating with social scientists in CHANS research.

Key Words: CHANS; coupled human and natural systems; integrated social and ecological models; interdisciplinary research; wildfire

\section{INTRODUCTION}

Coupled human and natural systems (CHANS) research has emerged as a new approach for studying complex social-ecological interactions. This trend coincides with growing policy interest among land management agencies in the United States to manage natural resources at landscape scales - across ownerships and administrative jurisdictions - such that policies and management correspond to the spatial scales of ecological processes and structure (e.g., U.S. Forest Service 2006, Collins and Larry 2007, Ager et al. 2015). Empirical models often are central to these research efforts, for representing complex interactions between humans and their environment, evaluating policy alternatives, and guiding policies toward greater resilience (Folke et al. 2002). Agent-based models (ABMs), in particular, are often used to integrate human behavior models with ecological models in CHANS studies, thereby enabling researchers to simulate human agents (or actors) engaging and interacting with other actors according to prescribed rules in a dynamic environment (e.g., Parker et al. 2003, Millington et al. 2008, An 2012, Rounsevell et al. 2012, Filatova et al. 2013). Such modeling efforts can aid in understanding human decision-making, revealing emergent behaviors that arise in CHANS that feature many actors with differing goals, and informing policy development (e.g., Chapin et al. 2006, Happe et al. 2006, Nagendra and Ostrom 2014).

A primary task for social scientists involved in CHANS modeling efforts is representing human behavior in empirical models. Conceptually, this involves characterizing how individual actors interact with their environment via landscape management decisions in response to biophysical and socioeconomic conditions (or feedbacks) (Anderies et al. 2004, Liu et al. 2007, Ostrom 2007, Spies et al. 2014). Actor-landscape interactions can take place at multiple spatial (e.g., parcel, landscape, region), temporal (e.g., short- versus long-term), and organizational scales via actors' management activities and interactions with other actors, agencies, and organizations (e.g., Pickett et al. 2005). However, designing and parameterizing CHANS empirical models to represent actor decision-making is challenging (Filatova et al. 2013). Some researchers devise actor decision rules based on theoretical, generalized, static, or scale-indeterminate assumptions about how actors behave, without actual empirical data that describe behavior. This can lead to erroneous model parameters, faulty representations of behavior, and ultimately oversimplified policies and practices should policy-makers attempt to use model results to inform policy (Ostrom 2007, Carpenter et al. 2009). In contrast, excessively complex representations of human behavior can be difficult to apply in management settings. Empirical data, when available and examined within appropriate theoretical frameworks, likely offer the greatest potential for representing CHANS processes to improve policy (e.g., Janssen and Ostrom 2006, Carpenter et al. 2009, Filatova et al. 2013). Such research necessitates multidisciplinary and interdisciplinary approaches that address a diversity of human system components (e.g., Rounsevell et al. 2012, Filatova et al. 2013).

For example, factors internal to the human system, such as individual actors' risk perceptions, beliefs, and environmental 
values (e.g., Paton 2003, Lindell and Perry 2012), tend to mediate behavioral responses to ecological conditions (Meyfroidt 2012). Adequately evaluating these factors can involve a combination of social science disciplines. Also, although CHANS ABMs tend to focus on individual actor behavior, there is increasing interest in how organizations (e.g., agencies, nongovernmental organizations, community groups) may influence actor behavior via social networks (e.g., Basu et al. 1998, Barton et al. 2000, Monticino et al. 2007, Honghui et al. 2010, Rounsevell et al. 2012). There also is a need for developing CHANS models that represent the influence of spatial factors on interactions among actors and their outcomes (e.g., Filatova et al. 2013) at broad spatial scales that are appropriate to addressing contemporary natural resource management issues. Given these needs, a key challenge for CHANS research teams is coordinating work among the often diverse social scientists tasked with developing the data and methods to represent actor behavior in CHANS empirical models. This includes identifying appropriate conceptual frameworks and theories to guide analysis, defining how data will be collected and analyzed, and developing ways to use the results of these efforts to devise decision rules or other representations of actor behavior for empirical models (e.g., ABMs).

Conducting interdisciplinary research is both a long-standing science goal and challenge in the United States and internationally (Daily and Ehrlich 1999, Metzger and Zare 1999, Tress et al. 2003), with integration of social and natural sciences an urgent priority (e.g., Redman et al. 2004, Shindler et al. 2017). Roy et al. (2013:745) defined interdisciplinary research as "scholars of different disciplines collaborating to develop terminology, research approaches, methodologies, or theories that are integrated across multiple disciplines." This differs from multidisciplinary research, which includes "perspectives and methods from several disciplines, [but where project] researchers still act within and preserve the exemplary concerns of their own discipline" (Klein 1990, Roy et al. 2013:745). Others have addressed challenges involved in conducting interdisciplinary research and offered guidelines to would-be practitioners. Many papers focus on overcoming conceptual, linguistic, perceptual, and philosophical differences among individual disciplines as barriers to interdisciplinary discourse and collaboration (e.g., Turner and Carpenter 1999, Eigenbrode et al. 2007). Crossdisciplinary research also can be challenged by operational difficulties in combining disparate concepts and methods from different disciplines (Eigenbrode et al. 2007:55-56), and associated lack of common vocabulary between biophysical and social scientists (e.g., Fox et al. 2006), among other factors. Some scholars have argued the benefits of using particular analytical "tools," including ABMs, to structure and facilitate integration among the multiple disciplines in research pertaining specifically to human-natural interactions (e.g., Zvoleff and An 2014). Researchers who attempt to integrate social and biophysical sciences are cautioned against simplifying or "compressing" one discipline in favor of others, such that a given discipline is reduced to overly simple equations or rules that do not adequately represent the "critical dimensions of the problem" under study (Wear 1999:300).

We drew on these developing interdisciplinary research guidelines to investigate and represent actor behavior within the CHANS of the fire-prone landscape of central Oregon. However, in addition to the recommendations outlined by others concerning interdisciplinary research, we suggest that those teams engaged in interdisciplinary efforts, and CHANS efforts specifically, could benefit from learning about how other similarly engaged scholars from diverse disciplines collaborated on CHANS projects. Such reflections could aid ongoing and future CHANS research efforts by identifying potential problem areas regarding data, analysis, and modeling issues, as well as how to organize and function as a team of diverse disciplines. This might enable other CHANS teams to avoid potential pitfalls (e.g., Turner and Carpenter 1999). Toward this end, we (1) briefly summarize what we learned about actor behavior on this fire-prone landscape and how we represented it in an ABM, and (2) more significantly, report on the challenges we encountered while working as a multidisciplinary team of social scientists to develop data and methods for representing actor behavior in a CHANS ABM. Our social science team spanned anthropology, economics, environmental history, political science, and sociology. Details about the CHANS project, ABM, and landscape simulations can be found in Barros et al. (2017), Spies et al. (2017), and Shindler et al. (2017). Details about individual social science contributions can be found in Charnley et al. (2017), Olsen et al. (2017), and Steen-Adams et al. (2017). We highlight the lessons we learned as a team of social scientists who developed decision rules for the ABM, identify challenges we encountered, and discuss their implications for CHANS research.

\section{STUDY CONTEXT AND SOCIAL SCIENCE OBJECTIVES}

Fire-prone landscapes feature several CHANS characteristics (Liu et al. 2007, Fischer et al. 2016a), including complexity, feedbacks lagged in time and space, and heterogeneity in the ways that different actors contribute to and mitigate wildfire risk (Ager et al. 2015). Wildfire risk, we assume, includes both the likelihood of wildfire and the likelihood of damage (e.g., Brenkert-Smith et al. 2006). Actors may be influenced by combinations of internal factors (e.g., wildfire risk perceptions, mitigation costs, and local forest conditions) and external factors (e.g., federal, tribal, and state land management policies, timber markets, and regional demographic trends) (Steelman 2010, Steelman and McCaffery 2011). Influencing factors (or variables) also can be "fast" or "slow" (Gunderson and Holling 2001, Folke 2006, Walker et al. 2012) depending on the amount of time it takes for a factor to manifest influence. In fire-prone landscapes, fast variables might include post-fire management, a new information campaign, an unusually active fire season, or rapid buildup of forest fuel following a wildfire or insect outbreak, for example. Slow variables might include changes in federal law, human demographic trends (e.g., in-migration), macroeconomic conditions, and the influence of climate change on the wildfire regime. Because slow variables operate over longer time frames, they can sometimes influence fast variables, for example, by imposing constraints on responsiveness to altered conditions (Carpenter and Turner 2000, Walker et al. 2012). Whether variables are fast or slow can affect the degree to which particular variables can be examined effectively using shortterm studies (e.g., Walker et al. 2012).

In our conceptual framing (Fig. 1), we assumed that the human system features a set of unique and interacting actor groups reacting to and in turn effecting changes to biophysical conditions and processes within the natural system according to their risk perceptions and management behaviors. These actor groups play two predominant roles: (1) public land management agencies and 
private forestland owners manage the landscape directly to influence biophysical variables (e.g., via harvesting or thinning to reduce stand density), which results in altered fuel conditions and corresponding changes in the likelihood of high-severity wildfire, among other landscape outcomes (Spies et al. 2017); and (2) agencies and organizations with an interest in wildfire management and policy strive to influence land managers and landowners through social networks - via business contacts, public meetings, person-to-person contacts, and involvement with formal incentive programs, among other civic activities (Fischer et al. 2013a, Fischer and Jasny 2017). In some cases, individual actors may play both roles, such as federal land management agencies (e.g., U.S. Forest Service) which might collaborate with local government agencies to coordinate wildfire risk mitigation efforts. We assumed that all these actors are influenced in their management or social network activities by biophysical variables that are relevant to wildfire and its management, including forest vegetation and stand structure, fuel conditions, and topography. In addition to these internal variables are external factors, including federal and state policy, commodity markets, and climate change, among others, that influence the CHANS of fireprone landscapes (Fig. 1). Within the natural system, for example, biophysical conditions interact with wildfire and climate regimes to produce a biophysical fire network (Ager et al. 2014). Although external drivers can influence CHANS variable dynamics, we assumed they remain largely uninfluenced by feedbacks in our study area landscape (e.g., Walker et al. 2012).

Fig. 1. Conceptual coupled human and natural system model of a fire-prone landscape.

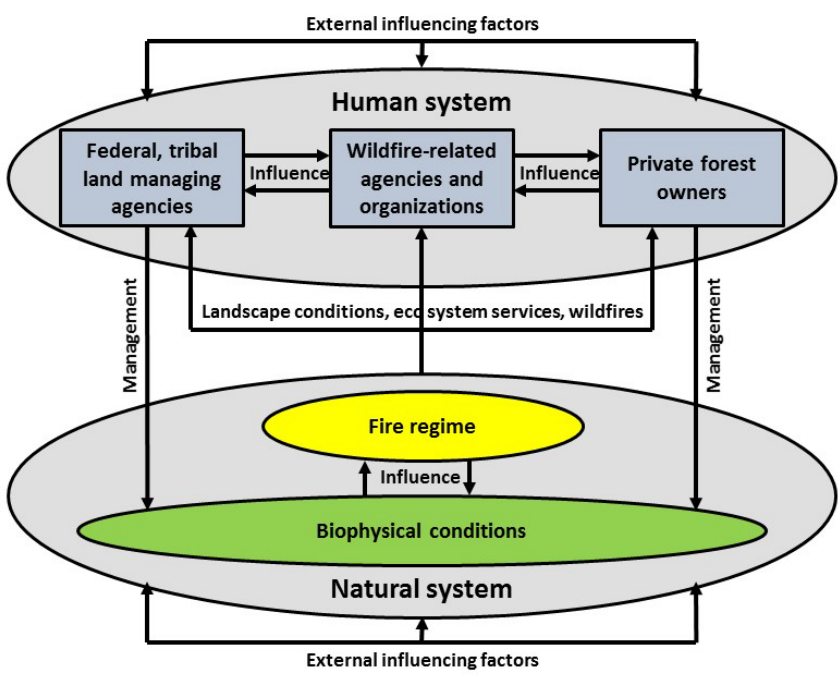

Our CHANS project proposed using systems models, integrated research, and collaborative learning to improve understanding of how human actors adapt to living in fire-prone forests (e.g., Walters 1986, Berkes and Folke 1994) and how existing policies could be made more effective. We conceptualized actor behavior as being influenced by biophysical and socioeconomic conditions and processes at various spatial and temporal scales, with actors both influencing and being influenced by landscape conditions (or feedbacks), such as wildfire hazard (Spies et al. 2014). We planned to (1) examine how land management policies, social networks and institutions, and actor behaviors interact to influence landscape dynamics and produce intended and unintended consequences for biodiversity and ecosystem services; (2) examine how sensitive landscape outcomes are to feedbacks via landscape patterns, social networks and institutions, and alternative policies; and (3) examine how external drivers, such as climate change and markets, might alter landscape outcomes. We were especially interested in representing the management behavior of agency or other organizational actors because fireprone landscapes commonly include significant public, tribal, or private corporate actors (e.g., Moritz et al. 2014). To advance these goals, project social scientists were tasked with identifying and characterizing factors - biophysical versus socioeconomic, internal versus external, and fast versus slow-that influence actors' forest management and wildfire risk mitigation behavior, and with using this information to parameterize actor decisionmaking in an ABM.

Our study area was central and south-central Oregon, east of the Cascade Mountains (Fig. 2). The area includes a diversity of ownerships, institutions, and land management objectives. The landscape features a patchwork of growing urban areas (Bend, OR) in the northern portion, and other small cities (Klamath Falls and Lakeview) in the south-central portion amidst a matrix of

Fig. 2. Central Oregon (USA) study area and major ownerships.

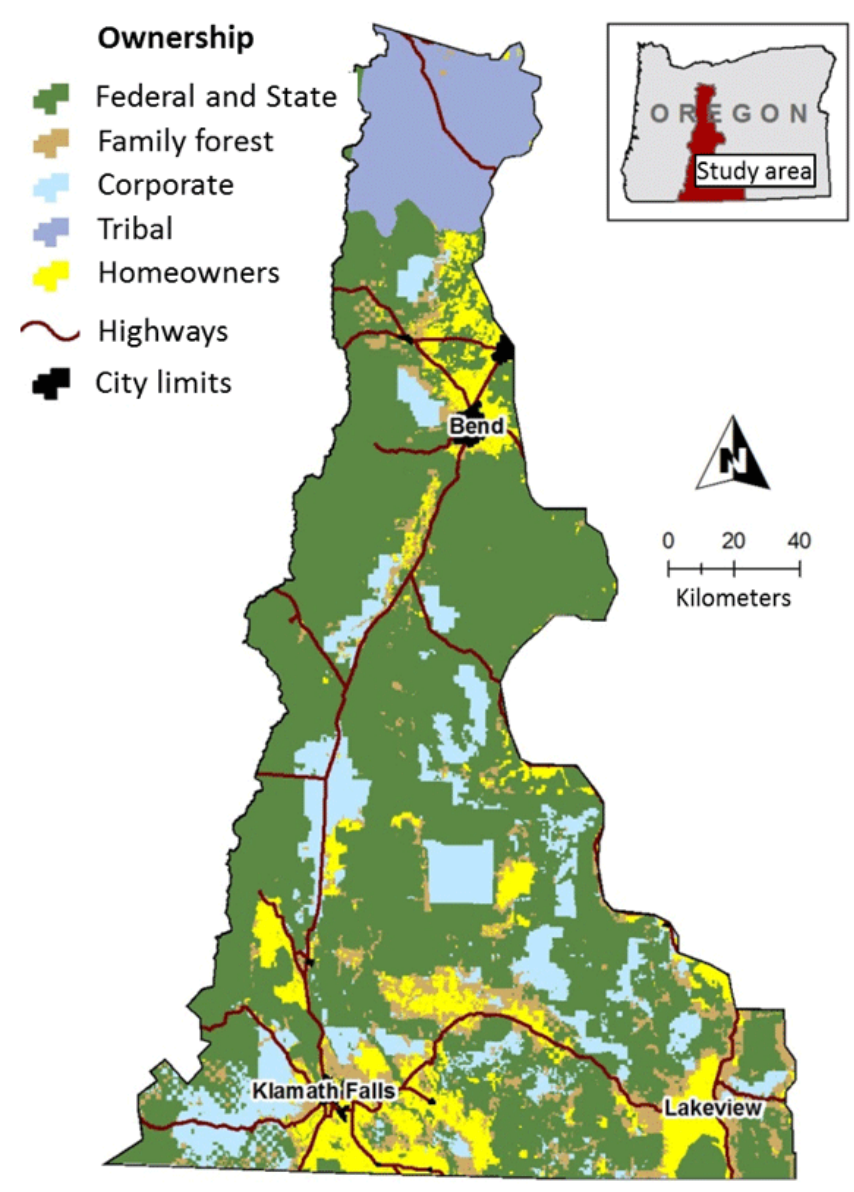


remote rural areas. Year-round and seasonal residents are drawn to the study area for its aesthetic and recreational amenities. Although historically the region experienced frequent wildfires, recent wildfires have been comparatively large and severe, and sometimes originate on the federally managed wildlands and spread to the wildland-urban interface (WUI) (Spies et al. 2014, Stine et al. 2014). These biophysical and socioeconomic circumstances challenge public officials and land managers to find ways to protect both forest resources and homes (Fischer et al. 2016a).

Six landscape actor groups occupy different shares of the landscape: federal government (58\% of the total land area), especially the U.S. Forest Service (48\%), state government (1\%), tribal $(8 \%)$, private corporate $(12 \%)$, and private individuals, including family forest owners (8\%) and WUI homeowners (12\%) (Fig. 3). Forest Service lands include the Fremont-Winema (912,676 ha) and Deschutes (648,308 ha) national forests, with a range of management objectives (Charnley et al. 2017). Tribal lands include the Confederated Tribes of the Warm Springs, which focus on commercial timber management and ecological restoration (Steen-Adams et al. 2017). Private corporate forest landowners $(10,000$ ha or more) typically have focused on commercial timber production but have undergone significant recent change, with landownership turnover among the largest companies, and divestment of timberlands by forest industries to Real Estate Investment Trusts and Timber Investment Management Organizations (Charnley et al. 2017). Private individual actors include family forest landowners (parcels 2 ha or greater) and homeowners (parcels less than 2 ha) located within the WUI. Their land management goals are highly variable, ranging from aesthetics, wildlife habitat, timber production, and privacy (e.g., Fischer et al. 2013b). We excluded urban landowners to focus on those lands that are most subject to, and influential on, wildfire risk.

Fig. 3. Distribution of study area land among landscape actors (BLM: Bureau of Land Management; WUI: wildland-urban interface).

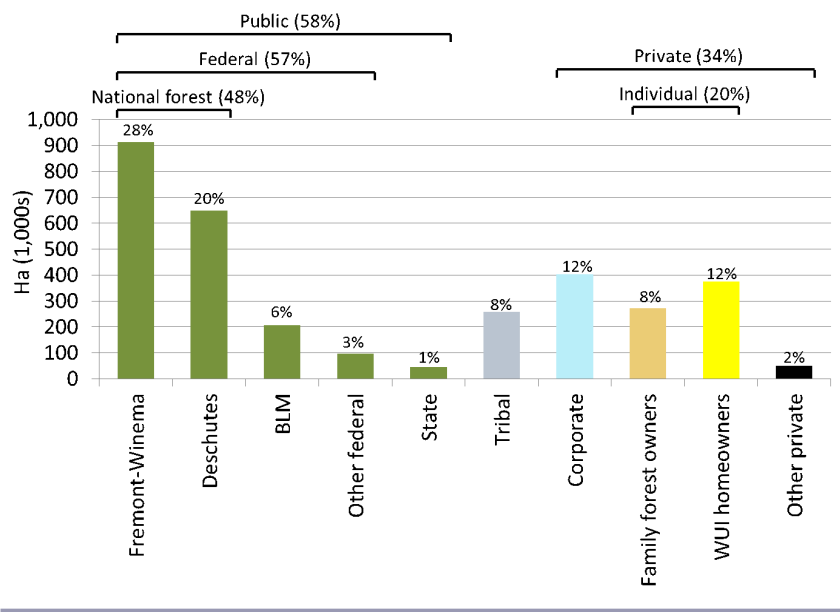

HOW WE CONDUCTED OUR SOCIAL SCIENCE WORK

Our project team began taking shape during the grant proposal writing phase, with a diverse array of social scientists invited to join a smaller group of ecologists, ecological engineer, and systems analysts to consider research questions we would address and methods we would use. We developed an initial integrative theoretical and methodological framework (e.g., Heemskerk et al. 2003, Redman et al. 2004) which the project team believed would accommodate the diverse theories and methods of our multidisciplinary team (Spies et al. 2014). The presumption that the ABM Envision (Spies et al. 2017) would be core to our research approach as a tool for integrating the work of disparate disciplines (e.g., Zvoleff and An 2014) was established by project leaders at the start, and was noted by proposal reviewers as a strength of our project proposal. Project leaders - a landscape ecologist and an ecological engineer-initially sought social scientist team members who expressed interest in helping develop information concerning actors' forest management and wildfire risk mitigation behaviors as they are influenced by key biophysical and socioeconomic conditions and processes related to wildfire, for use in developing decision rules for representing actor behavior in the ABM. Additional social scientists were added to the project along the way when it was felt they had expertise that might aid the project. Project leaders sought to secure a range (or "portfolio") of social science expertise, including some potential redundancy in interests and skill sets, to ensure there was sufficient capacity over the multiyear course of the project to address the diverse array of human-natural interactions that characterize wildfire management issues in fire-prone landscapes.

Following proposal funding, the project got underway with more than 10 social scientists formally listed as participants. These included an anthropologist, three economists, an environmental historian, a political scientist, and four sociologists, as well as several graduate students who participated in different phases of the project. Specific social science research tasks pertaining to investigating actor behavior and developing decision rules for the ABM were assigned using largely an ad hoc process whereby individuals initiated work based on their own prior interests and using methods with which they were most familiar. The anthropologist who had previously studied federal land managers planned to collect and analyze data using qualitative methods to examine federal and state land managers and corporate forest owners (Table 1). The environmental historian with an interest in Native American tribes planned to use mostly qualitative methods to examine that actor group. A sociologist with experience in studying homeowners examined that group, while the economists previously involved with family forest owners examined that group. Other project social scientists either did not involve themselves directly in examining actor behavior in a manner that facilitated development of decision rules for the ABM or examined broader contextual issues such as public attitudes toward wildfire and stakeholder engagement, again somewhat commensurate with their own prior research interests.

Although the specific methods used to examine each actor group aligned with the disciplinary focus of the particular social scientist (s) who led the examination of each group, method choice also was based in part on characteristics of the actor groups themselves, including the number of distinct entities or individuals within each group. Although federal and state agencies, tribes, and private corporate owners manage most $(68 \%)$ of the study area landscape, the number of individual managers is low (Table 1). Thus, the anthropologist and environmental 
Table 1. Primary actor groups identified, specific entities examined, and approaches to data collection and analysis (WUI: wildlandurban interface; BLM: Bureau of Land Management; NEPA: National Environmental Policy Act).

\begin{tabular}{|c|c|c|c|c|c|c|}
\hline \multirow[b]{2}{*}{ Actor group } & \multirow[b]{2}{*}{$\begin{array}{l}\text { Total number of } \\
\text { entities }\end{array}$} & \multirow[b]{2}{*}{$\begin{array}{l}\text { Number of } \\
\text { entities examined }\end{array}$} & \multirow[b]{2}{*}{$\begin{array}{l}\text { Discipline of lead } \\
\text { scientist }\end{array}$} & \multicolumn{2}{|c|}{ Data sources } & \multirow[b]{2}{*}{$\begin{array}{l}\text { Analytical } \\
\text { method }\end{array}$} \\
\hline & & & & Primary & Secondary & \\
\hline $\begin{array}{l}\text { Federal land } \\
\text { managers }\end{array}$ & $\begin{array}{l}\text { Two national forests, } \\
\text { BLM, and several } \\
\text { smaller holdings }\end{array}$ & $\begin{array}{l}\text { Two national } \\
\text { forests }\end{array}$ & Anthropology & $\begin{array}{l}\text { Interviews with } 82 \\
\text { employees at district, } \\
\text { regional, and national } \\
\text { offices }\end{array}$ & $\begin{array}{l}\text { Management plans, NEPA } \\
\text { documents, activity databases }\end{array}$ & $\begin{array}{l}\text { Qualitative } \\
\text { content } \\
\text { analysis }\end{array}$ \\
\hline State & $\begin{array}{l}\text { Two state forests, and } \\
\text { several smaller } \\
\text { holdings }\end{array}$ & Two state forests & Anthropology & $\begin{array}{l}\text { Interview with sole } \\
\text { manager of both } \\
\text { state forests }\end{array}$ & Management plan & $\begin{array}{l}\text { Qualitative } \\
\text { content } \\
\text { analysis }\end{array}$ \\
\hline $\begin{array}{l}\text { Native American } \\
\text { tribes }\end{array}$ & $\begin{array}{l}\text { Two tribes, one of } \\
\text { which governs land }\end{array}$ & One tribe & $\begin{array}{l}\text { Environmental } \\
\text { history }\end{array}$ & $\begin{array}{l}\text { Interviews with } \\
18 \text { past and current } \\
\text { decision-makers }\end{array}$ & $\begin{array}{l}\text { Management plan, } \\
\text { archival documents }\end{array}$ & $\begin{array}{l}\text { Qualitative } \\
\text { content } \\
\text { analysis }\end{array}$ \\
\hline $\begin{array}{l}\text { Corporate forest } \\
\text { owners }\end{array}$ & Five corporations & $\begin{array}{l}\text { Five } \\
\text { corporations }\end{array}$ & Anthropology & $\begin{array}{l}\text { Interviews with one } \\
\text { manager each for five } \\
\text { corporations }\end{array}$ & $\begin{array}{l}\text { Certification reports, } \\
\text { activity notifications }\end{array}$ & $\begin{array}{l}\text { Qualitative } \\
\text { content } \\
\text { analysis }\end{array}$ \\
\hline $\begin{array}{l}\text { Family forest } \\
\text { owners ( } \geq 2 \text { ha) }\end{array}$ & Estimated $>8000$ & Survey sample & Economics & $\begin{array}{l}379 \text { responses to mail } \\
\text { survey }\end{array}$ & $\begin{array}{l}\text { Peer-reviewed research } \\
\text { literature }\end{array}$ & $\begin{array}{l}\text { Logistic } \\
\text { regression }\end{array}$ \\
\hline $\begin{array}{l}\text { Homeowners } \\
(<2 \text { ha in WUI })\end{array}$ & $\begin{array}{l}\text { Estimated in tens } \\
\text { of thousands }\end{array}$ & Survey sample & Sociology & $\begin{array}{l}531 \text { responses to mail } \\
\text { survey }\end{array}$ & $\begin{array}{l}\text { Peer-reviewed research } \\
\text { literature }\end{array}$ & $\begin{array}{l}\text { Logistic } \\
\text { regression }\end{array}$ \\
\hline
\end{tabular}

historian used qualitative content analysis (Flick 2014) of transcripts from in-person, semistructured interviews of managers and reviews of secondary data sources (e.g., management documents and activity reports) to investigate the behavior of these actor groups (Charnley et al. 2017, SteenAdams et al. 2017). Family forest landowners and homeowners collectively manage a much smaller portion of the study area landscape but are more numerous and variable than government, tribal, or corporate actors (Table 1). Thus, the sociologist and economists who examined individual landowners used mail surveys to investigate these actor groups. Grounded in conceptual framing developed by Fischer et al. (2014), their analyses relied on logistic regression to describe the statistical likelihood that individual homeowners and family forest landowners conducted various management and wildfire risk mitigation activities as a function of explanatory variables that represented key biophysical and socioeconomic influencing factors (e.g., Olsen et al. 2017).

The body of social science conducted for the CHANS project thus comprised several substudies that were largely grounded in the specific discipline and research interest of the social scientist (s) who led the investigation of each actor group. For each actor group, substudies sought to (1) examine the landscape management activities that actors undertake; (2) explain actors' decision-making processes, including their goals, decision frameworks (e.g., policy directives), and wildfire risk perceptions; (3) identify biophysical and social factors that influence actors' forest management and wildfire risk mitigation behaviors; and (4) use these data to develop decision rules to be programmed into the ABM to represent actors' behaviors. Additional details about some of these individual substudies can be found in Charnley et al. (2017), Olsen et al. (2017), and Steen-Adams et al. (2017). The result was the application of a mix of methodological approaches to examine the forest management and wildfire risk mitigation behaviors of the different actor groups. This paralleled the mixed- methods approach taken by the project's biophysical scientists (Spies et al. 2017), consistent with a "hybrid" approach to agentbased modeling (O'Sullivan et al. 2016).

The foregoing discussion should not give the impression that our project was absent of any cross-disciplinary social science collaboration. To the contrary, some cross-disciplinary social science collaboration did occur but somewhat on an "as needed" basis. For example, given the quantitative nature of the ABM, the anthropologist who used qualitative methods to examine federal and state land managers and corporate forest owners sought assistance from one of the economists to devise empirical decision rules for those actor groups based on the qualitative data collected. The sociologist who examined homeowners collaborated with another one of the economists who assisted in developing probabilistic regression equations that described the likelihood that homeowners performed structure and landscape fire-proofing activities, using methods similar to those the economists used to examine family forest owners. The involvement of the economists in facilitating development of many of the actor decision rules for the $\mathrm{ABM}$ was due in part to their relative greater interest in and comfort with quantitative methods. These characteristics enabled the economists to work somewhat as intermediaries between the qualitative project social scientists and the systems analysts who were developing the ABM.

\section{WHAT WE LEARNED ABOUT ACTOR BEHAVIOR AND HOW TO REPRESENT IT IN AN AGENT-BASED MODEL}

We identified a variety of management objectives and activities among and within the actor groups (Table 2). Internal biophysical factors that influenced management decisions included stand density, age, and structure, and wildfire hazard, for example, while internal socioeconomic variables that influenced management decisions included harvest costs and landowners' and homeowners' contacts with wildfire-related agencies and organizations. External socioeconomic variables that influenced 
Table 2. Forest management and wildfire risk mitigation activities of actor groups, and primary influencing factors identified (WUI: wildland-urban interface).

\begin{tabular}{|c|c|c|c|c|}
\hline \multirow[b]{2}{*}{ Actor group } & \multirow[b]{2}{*}{ Management objectives } & \multirow[b]{2}{*}{ Principal management activities } & \multicolumn{2}{|c|}{ Primary influencing factors } \\
\hline & & & Biophysical & Socioeconomic \\
\hline $\begin{array}{l}\text { Federal land } \\
\text { managers }\end{array}$ & $\begin{array}{l}\text { Forest restoration, } \\
\text { reduction in wildfire risk }\end{array}$ & $\begin{array}{l}\text { Thinning, mowing, mastication, prescribed } \\
\text { burning, salvage, fire suppression }\end{array}$ & $\begin{array}{l}\text { Forest type, wildfire hazard, } \\
\text { stand stocking, topography }\end{array}$ & $\begin{array}{l}\text { Federal policy, budget } \\
\text { priorities, WUI location, } \\
\text { resources at risk, access }\end{array}$ \\
\hline State & $\begin{array}{l}\text { Timber revenue, reduction } \\
\text { in risk from wildfire, insects, } \\
\text { and disease }\end{array}$ & $\begin{array}{l}\text { Harvest, thinning, piling and burning, fuel } \\
\text { breaks, fire suppression, tree planting }\end{array}$ & $\begin{array}{l}\text { Stand stocking, topography, } \\
\text { wildfire hazard, insects and } \\
\text { disease threats }\end{array}$ & $\begin{array}{l}\text { State policy, WUI location, } \\
\text { communities and travel } \\
\text { corridors, timber prices, } \\
\text { harvest costs, access }\end{array}$ \\
\hline $\begin{array}{l}\text { Native American } \\
\text { tribes }\end{array}$ & $\begin{array}{l}\text { Forest restoration, } \\
\text { protection of life, property, } \\
\text { cultural resources }\end{array}$ & $\begin{array}{l}\text { Harvest, thinning, mowing, mastication, } \\
\text { prescribed burning, fire suppression }\end{array}$ & $\begin{array}{l}\text { Wildfire hazard, WUI, } \\
\text { stand stocking, topography, } \\
\text { proximity to water }\end{array}$ & $\begin{array}{l}\text { Tribal policy, WUI location, } \\
\text { demographics, timber prices } \\
\text { and harvest costs, access }\end{array}$ \\
\hline $\begin{array}{l}\text { Corporate forest } \\
\text { owners }\end{array}$ & $\begin{array}{l}\text { Financial return, with risk } \\
\text { mitigation as a secondary } \\
\text { outcome }\end{array}$ & $\begin{array}{l}\text { Harvest, thinning, burning slash piles, } \\
\text { salvage, fire suppression }\end{array}$ & $\begin{array}{l}\text { Stand stocking, topography, } \\
\text { wildfire hazard, WUI, } \\
\text { insects and disease threats }\end{array}$ & $\begin{array}{l}\text { Annual revenue targets, } \\
\text { timber prices and harvest } \\
\text { costs, access }\end{array}$ \\
\hline $\begin{array}{l}\text { Family forest } \\
\text { owners ( } \geq 2 \text { ha) }\end{array}$ & $\begin{array}{l}\text { Reduction in wildfire } \\
\text { hazard, financial return, } \\
\text { recreation, amenities }\end{array}$ & $\begin{array}{l}\text { Timber harvest, thinning, mowing, } \\
\text { prescribed burning }\end{array}$ & $\begin{array}{l}\text { Stand density and stocking, } \\
\text { topography, past wildfire, } \\
\text { insects and disease }\end{array}$ & $\begin{array}{l}\text { Presence of structure, timber } \\
\text { prices and harvest costs, } \\
\text { access, contact with U.S. } \\
\text { Forest Service }\end{array}$ \\
\hline $\begin{array}{l}\text { Homeowners } \\
(<2 \text { ha in WUI })\end{array}$ & Reduction in wildfire risk & Structure and landscape fire-proofing & $\begin{array}{l}\text { Burn probability, potential } \\
\text { conditional flame length, } \\
\text { past wildfire, stand density }\end{array}$ & $\begin{array}{l}\text { Homeowner association } \\
\text { rules, contact with local fire } \\
\text { department or fire awareness } \\
\text { groups }\end{array}$ \\
\hline
\end{tabular}

Note: Details on specific actor results can be found in Charnley et al. (2017), Steen-Adams et al. (2017), and Olsen et al. (2017).

behavior included federal policy, annual revenue targets, public support, and timber prices. Some "fast" influencing variables included the degree of wildfire hazard associated with fuel conditions, past wildfire, and tree mortality from insects and disease. Examples of "slow" influencing factors included federal habitat protection and endangered species policies, population and housing growth and associated expansion of the WUI which bolsters political support for federal and state wildfire protection policies, and demographics (Table 2).

We found that the varied characteristics of the actor groups and the varied ways we examined them called for using different approaches to develop decision rules for each actor group. Details about these decision rules can be found in Spies et al. (2017). We developed decision rules for federal and state land managers, tribes, and corporate forest landowners as sets of heuristics that reflected manager interviews, existing management plans, planning documents, and expert opinion (Table 3). We represented their timber harvest decisions using a target-based approach derived from annual harvest targets for each owner, combined at each model time-step with an ordinal ranking of stands that met desired harvest characteristics. We based the noncommercial fuel reduction activities of federal and tribal actors on annual treatment targets, combined at each model timestep with stand characteristics that were identified by managers as indicating suitable treatment opportunities, including priorities that concerned particular forest values (e.g., habitat), timber productivity, fuel loads, WUI designation, and transportation infrastructure (Table 3). We based our decision rules for individual private landowners on logistic regression analysis of specific survey questions that pertained to family forest owners' harvest and fuel reduction activities and homeowners' structure and landscape fire-proofing activities (Olsen et al. 2017), following Fischer et al. (2014). We used the resulting regression equations in the ABM to compute probabilities that family forest owners and homeowners would conduct particular activities at each modeling time-step as a function of key biophysical and socioeconomic variables (Table 3 ).

Our CHANS research resulted in several insights and accomplishments regarding forest policy management in fireprone landscapes. The decision rules enabled us to use the ABM to simulate the management behavior of the actor groups over 50 years for current and alternative landscape-scale management scenarios to understand both their feasibility and the social and ecological conditions that result from joint management strategies (Charnley et al. 2017, Spies et al. 2017). In these simulations, management actions combined with succession and natural disturbance to determine projected biophysical conditions across the study area landscape. These simulated biophysical changes in turn served as landscape feedbacks which influenced whether actors could or would choose to implement particular management actions during each simulation year. We found that the federal government was a key actor group in our study area (Charnley et al. 2017), and attempts at representing policies, programs, and norms of agency actors could inform other CHANS research. We also mapped wildfire suppression and fuels management networks (Fischer et al. 2016b). We found that exposure to fire suppression and wildfire-related agencies and organizations influences the likelihood that individual private landowners conduct risk mitigation activities (Olsen et al. 2017, Spies et al. 2017). The ABM currently is being used to evaluate alternative landscape-scale management strategies in participatory modeling (e.g., O'Sullivan et al. 2016) with formal forest collaborative groups.

We were able to address a number of CHANS characteristics. We identified combinations of influencing factors, including 
Table 3. Representation of actors' forest management and wildfire risk mitigation activities in the agent-based model Envision (WUI: wildland-urban interface).

\begin{tabular}{|c|c|c|c|c|}
\hline \multirow[b]{2}{*}{ Actor group } & \multirow[b]{2}{*}{$\begin{array}{l}\text { Management activities } \\
\text { represented in Envision }\end{array}$} & \multirow[b]{2}{*}{ Approach } & \multicolumn{2}{|c|}{ Decision rule parameters } \\
\hline & & & Biophysical & Socioeconomic \\
\hline $\begin{array}{l}\text { Federal land } \\
\text { managers }\end{array}$ & $\begin{array}{l}\text { Harvest (thinning from below, } \\
\text { salvage logging), reduce fuel } \\
\text { (prescribed burning, mowing/ } \\
\text { grinding) }\end{array}$ & $\begin{array}{l}\text { Target-based (volume } \\
\text { and area) allocation } \\
\text { heuristic }\end{array}$ & $\begin{array}{l}\text { Harvest: commercial species forest } \\
\text { types, tree size }>10 "(25.4 \mathrm{~cm}) \text {, closed } \\
\text { canopy, basal area, potential fire } \\
\text { severity, stand slope }<30 \% \\
\text { Reduce fuel: high fire frequency forest } \\
\text { types, tree size }>10^{\prime \prime}(25.4 \mathrm{~cm}) \text {, single } \\
\text { story stands, low to moderate canopy } \\
\text { closure, potential fire severity, fast- } \\
\text { spread fuels }\end{array}$ & $\begin{array}{l}\text { Harvest: "Suitable for harvest" } \\
\text { designation, not Wilderness, no } \\
\text { endangered species nesting } \\
\text { habitat, 14+ years since previous } \\
\text { activity, WUI proximity } \\
\text { Reduce fuel: "Suitable for } \\
\text { harvest" designation, time since } \\
\text { previous treatment, not } \\
\text { Wilderness, no endangered } \\
\text { species nesting habitat, proximity } \\
\text { to roads }\end{array}$ \\
\hline State land managers & Harvest (selection cutting) & $\begin{array}{l}\text { Target-based (area) } \\
\text { allocation heuristic }\end{array}$ & Commercial species forest types & - \\
\hline $\begin{array}{l}\text { Native American } \\
\text { tribes }\end{array}$ & $\begin{array}{l}\text { Harvest (thinning, clearcutting, } \\
\text { salvage logging), reduce fuel } \\
\text { (prescribed burning) }\end{array}$ & $\begin{array}{l}\text { Target-based (volume } \\
\text { and area) allocation } \\
\text { heuristic }\end{array}$ & $\begin{array}{l}\text { Harvest: commercial species forest } \\
\text { types, minimum stand age, slope, } \\
\text { distant from streams } \\
\text { Reduce fuel: high fire frequency forest } \\
\text { types, fast-spread fuels }\end{array}$ & $\begin{array}{l}\text { Harvest: "Suitable for harvest" } \\
\text { designation, time since prior } \\
\text { activity, no endangered species } \\
\text { nesting habitat, WUI proximity, } \\
\text { road proximity } \\
\text { Reduce fuel: time since previous } \\
\text { treatment }\end{array}$ \\
\hline $\begin{array}{l}\text { Corporate forest } \\
\text { owners }\end{array}$ & $\begin{array}{l}\text { Harvest (selection cutting, } \\
\text { salvage) }\end{array}$ & $\begin{array}{l}\text { Target-based } \\
\text { (volume) allocation } \\
\text { heuristic }\end{array}$ & $\begin{array}{l}\text { Any forested type, high basal area ( }> \\
23 \mathrm{~m}^{2} / \text { ha) preferred, slope }<30 \% \text { for } \\
\text { salvage logging }\end{array}$ & $\begin{array}{l}\text { More than } 19 \text { years since } \\
\text { previous harvest, proximity to } \\
\text { roads }\end{array}$ \\
\hline $\begin{array}{l}\text { Family forest owners } \\
(\geq 2 \text { ha) }\end{array}$ & $\begin{array}{l}\text { Harvest (thinning from below), } \\
\text { reduce fuel (thinning, mowing/ } \\
\text { grinding, prescribed burning) }\end{array}$ & $\begin{array}{l}\text { Probabilistic } \\
\text { regression equation }\end{array}$ & $\begin{array}{l}\text { Harvest: basal area, size of parcel } \\
\text { Reduce fuel: trees per hectare, recent } \\
\text { wildfire near parcel }\end{array}$ & $\begin{array}{l}\text { Harvest: none } \\
\text { Reduce fuel: structure present on } \\
\text { parcel }\end{array}$ \\
\hline $\begin{array}{l}\text { Homeowners } \\
(<2 \text { ha in WUI })\end{array}$ & $\begin{array}{l}\text { Any landscape or structure fire- } \\
\text { proofing activity }\end{array}$ & $\begin{array}{l}\text { Probabilistic } \\
\text { regression equation }\end{array}$ & $\begin{array}{l}\text { Burn probability, potential conditional } \\
\text { flame length, trees per hectare, recent } \\
\text { wildfire near home }\end{array}$ & $\begin{array}{l}\text { Recent prescribed burning near } \\
\text { home }\end{array}$ \\
\hline
\end{tabular}

Note: Additional details about the decision rules developed for the actor groups, as well as the landscape simulations, can be found in Spies et al. (2017).

biophysical, socioeconomic, internal, external, slow, and fast, for the actors we examined. We found that some of these factors operate as two-way feedbacks, which influence actors' forest management and wildfire risk mitigation activities, which in turn influence biophysical (e.g., vegetation, fuel) conditions. We were able to use qualitative and quantitative data and hypothesis testing, rather than relying on purely theoretical assumptions, to develop predictive models of actor behavior to aid in simulating CHANS dynamics over time in an ABM (e.g., Spies et al. 2017). However, much of our social science research also involved developing a fundamental understanding of the social landscape of this fire-prone CHANS, including identifying key actors and the biophysical and socioeconomic factors that influence them. In this regard, much of our social science work necessarily involved more discipline-focused data collection, analysis, and hypothesis testing, over integrative development of CHANS theory pertaining to fire-prone landscapes.

We also found that developing empirical models that capture some actor responses to wildfire hazard is challenging, in part because fire signal frequency is low at fine spatial and temporal scales (Spies et al. 2017). This characteristic may make it difficult both for actors to perceive and react to wildfire risk and for social scientists to observe such effects using biophysical and socioeconomic data collected over short periods. Additionally, in our project, we found that some of the landscape management and wildfire risk mitigation activities conducted by some actors were too subtle or small to be influential in biophysical models that operated at the spatial scale we had chosen to represent the fairly large geography of our study area. For example, homeowners may effect changes in landscaping around their homes by conducting wildfire risk mitigation activities, but even if most homeowners perform such activities, the net change in fuel conditions at the spatial grain of the biophysical models used in the ABM may be negligible. This was the case for our modeling with all of the landscape and structure Firewise activities that homeowners reasonably might conduct. Additionally, our wildfire behavior model did not simulate fire movement at a spatial scale that was sufficient to discern house-to-house fire movement. As a result, we had to account for the potential effectiveness of homeowners' risk mitigation activities by assuming an improved rate of structure survival when Firewise activities were adopted (Olsen et al. 2017). We also found that some actors (e.g., family forest owners and homeowners) are quite varied in how they implement fuels management activities, which presented additional challenges when these behaviors similarly could not be represented at the spatial scale of a given biophysical model.

We made limited progress in representing social network influences on actor behavior as social network feedbacks in our ABM. In hindsight, we may have been overly ambitious in this 
goal at the outset given the relative lack of available research on key network components, structure, and function. Although we did find statistically significant social network effects in our actor behavior models for family forest owners and homeowners (e.g., Olsen et al. 2017), we were unable to fully represent these in the ABM because of limitations in our ability to model changes in social networks themselves. Difficulties arose mostly because we did not collect empirical information that described interactions among social network dynamics, actor behavior, and landscape change. Moreover, the large numbers of individual actors and social connections among them, and their heterogeneity, defied easy characterization for CHANS modeling. However, our work has better positioned us to pursue this goal in the future. The estimated regression coefficients that described social network influences on family forest owner and homeowner management behavior provide a coarse empirical link between existing social networks and the simulated management and mitigation activities of these actors should a dynamic social network simulation model ever be developed. Continued advancement of methods for representing social wildfire-related networks in CHANS empirical modeling (e.g., Fischer et al 2013a, 2016b, and Fischer and Jasny 2017) could present such opportunities in the future.

We also made less progress than we had hoped in characterizing institutional behavior of federal and state actors. Behavior of these actors conceivably can be influenced by a broad array of external social, economic, and political factors in addition to agency-specific policy goals and the largely internal biophysical variables we examined. For example, the number of resources used in wildfire suppression by public agencies can be sensitive to media coverage and political pressure (Donovan et al. 2011), which suggests that biophysical feedbacks can occur indirectly through political and social network processes in addition to the more direct landscape-to-actor pathways we examined. Also, it is conceivable that population and housing growth, and its impact on wildfire risk in the WUI, tends to embolden political interest in maintaining federal and state policies that favor current wildfire suppression over alternative approaches to addressing wildfire. Alternatives might include, for example, reducing suppression efforts to save homes from approaching wildfire in favor of expanding efforts to encourage homeowners to take greater responsibility for their own residential location choices and reduce their own exposure to fire risk through increased risk mitigation activities that are focused on their property and structure. Although our initial intent was to incorporate such indirect feedbacks into our ABM, ultimately we lacked the time and resources to do so.

\section{CHALLENGES WE ENCOUNTERED IN REPRESENTING ACTOR BEHAVIOR IN A COUPLED HUMAN AND NATURAL SYSTEMS AGENT-BASED MODEL}

We also observed several interrelated challenges in working as a team of diverse social scientists who collaborated with biophysical scientists to develop data and methods for representing actor behavior in our CHANS ABM. We summarize these challenges according to several themes.

\section{Quantitative versus qualitative data and analysis}

At the outset, it was apparent that how familiar and comfortable individual social scientist team members were with collecting and analyzing actor behavior data quantitatively (versus qualitatively) might influence the degree to which their work would contribute directly to developing actor decision rules for the ABM. Those team members who were most comfortable working quantitatively or who actively engaged with other team members who were comfortable working quantitatively (often the economists) saw their work contribute more directly to the ABM than did qualitative team members who did not actively engage quantitative team members. With almost all actor groups, one or another of the economists on the team necessarily played somewhat of an intermediary role in facilitating the transformation and transfer of data and analysis developed by more qualitatively inclined team members to the various biophysical scientists and systems analysts who prepared the various biophysical models that were used to represent ecological and wildfire processes and program the ABM. In some cases, research efforts by qualitative team members who did not work directly with a quantitative team member resulted in analyses and insights that were more contextual and were not directly incorporated into the ABM. These efforts included surveys of public attitudes concerning wildfire and its management, development of an environmental history of tribal, federal, and private corporate lands in the study area, and stakeholder outreach and engagement, among others, all of which were valuable contributions in their own right to enhancing understanding of this CHANS.

\section{Distilling complex human system processes into simple models}

We were challenged by having to represent actor behavior using limited sets of decision rules. The decision rules we developed for each actor group necessarily focused only on the most prevalent forest management and wildfire risk mitigation activities found among each group, and on the most consequential for biophysical conditions and processes evaluated by the ecological and wildfire models used to represent the natural system. Such simplification arguably is almost always necessary in CHANS empirical modeling because models can address only a limited range of activities and influencing factors. An outcome for us was that decision rules ultimately focused on a reduced set of biophysical and socioeconomic influencing variables, mostly fast and internal to the CHANS we studied and corresponding to specific variables recognized by the biophysical models we used to describe ecological and wildfire conditions and processes. We necessarily excluded several forest management and risk mitigation behaviors, largely owing to difficulties in representing them at the spatial and temporal scales of our ABM. Excluded influencing variables tended to be slow or external. For example, federal wildfire suppression policy and treatment targets, and population and housing growth all influence when and where federal managers place fuel reduction treatments (e.g., Paveglio and Prato 2012), but none of these factored into our ABM as endogenous variables or feedbacks, and so our ABM is "static" regarding these effects.

At the outset, we had to establish bounds on the scope of what biophysical-socioeconomic feedbacks we could examine and represent in the Envision model. Given the broad spatial scale at which we were working and the existing structure of the Envision model, interactions between biophysical conditions and landscape managers and landowners were deemed most feasible. We found that representing feedbacks that involved broader socioeconomic factors, such as political dynamics and markets, 
was more challenging. In the case of population and housing growth, for example, one of the biggest factors that influences rates and patterns of housing development in Oregon is the statewide land use planning program, which is administered at the county level but under the oversight of the State's Land Conservation and Development Commission (e.g., Kline et al. 2014). Any reasonable attempt to model population and housing growth in a dynamic way necessarily would involve developing decision rules that outline how wildfires would influence political, economic, or social dynamics in a way that resulted in modified land use plans and policies, and eventually changes in inmigration and housing development. Similar to our difficulties in incorporating social networks into the Envision model, we found the possibility of incorporating these broader political, economic, or social dynamics beyond our capacity in the current project.

\section{Varying sensitivity of biophysical models to social variables and models}

Our omission of particular actor behaviors and influencing factors was due in some cases to the unresponsiveness (at the spatial and temporal scales of our ABM) of particular biophysical models to management and risk mitigation activities that actors said they conducted. Two examples included (1) the inability of our fuel model to react to changes in fuel conditions in response to precommercial thinning, which conceivably would reduce fuel, and (2) the inability of our wildfire behavior model to react to structure- and landscape fire-proofing activities conducted by homeowners, which conceivably could influence wildfire behavior and suppression effort. In both cases, constraints on project resources necessitated that we rely on already established and generally accepted models, with little opportunity for tailoring them to our specific application and the spatial scale at which we were working (Barros et al. 2017, Spies et al. 2017). Whether such omissions meaningfully influenced our results is uncertain. Some human behavior can seem significant to individual actors but may not be all that significant at the landscape-scale of our analysis. However, the degree to which progress can be made toward representing two-way feedbacks (e.g., Parker et al. 2008, Filatova et al. 2013) depends in part on whether biophysical models can be responsive to modeled landscape management activities at the spatial scales at which we conduct CHANS research. Regarding CHANS in fire-prone landscapes, focused research may be necessary to identify what human activities indeed matter for key biophysical conditions and processes, and to consider at what spatial scales they can be represented in biophysical models. Such research could indicate needed improvements in biophysical modeling and provide new opportunities for integrating biophysical and socioeconomic information in empirical modeling.

\section{Synchronization of research tasks involving social and natural systems}

We found that, in some cases, the timing of research tasks influenced what CHANS interactions we could address in our ABM. For example, project time constraints meant that actor interviews and surveys, intended to provide data and analysis for developing actor decision rules, were ongoing simultaneous to ABM development. In some cases, this created disconnects between what was being learned about actor behaviors and the biophysical and socioeconomic variables that influence them, and which of these could be represented or modeled in the ABM. If social scientists on the project team had a better sense about what was being learned by the biophysical scientists and systems analysts about which management activities would be possible to represent in the various biophysical models and the ABM, before they conducted their interviews and surveys, they might have structured particular interview or survey questions differently. Similarly, if biophysical scientists and systems analysts had had a better sense about what management activities the social scientists were finding were most prevalent or were perceived by actors as most significant, they might have had opportunities to revise biophysical models or reconsider the spatial scale of the ABM. Despite near monthly project-wide team meetings, we often tended to experience concurrent (but not necessarily always collaborative) learning about what actor management activities and influencing factors were prevalent and which would be feasible to model at the spatial scales selected for the ABM.

\section{Substituting spatial for temporal variation in social data and models}

We found difficulties in using cross-sectional data to characterize actors' behavioral responses to time-dynamic biophysical and socioeconomic variables. Social science often relies on interviews and surveys conducted over narrow windows (or "snapshots") in time. This can make it difficult or impossible to identify behavioral changes over longer time frames. In some cases, it may not be that a behavior or influencing factor does not matter, but rather that its effect or influence cannot be evaluated using cross-sectional data. For example, the central Oregon part of our study area included a well-developed organizational network that was focused on increasing awareness about wildfire and how landowners could reduce their risk (Fischer and Jasny 2017). Because nearly all landowners sampled in central Oregon had had recent contact with this network, there were too few survey respondents in our sample to reliably estimate how absence of such a network would influence risk mitigation effort. To examine this effect, we had to substitute spatial for temporal variation by using the survey sample from the south-central part of our study area (Hall 2015), where the wildfire organizational network was less developed, to evaluate how network absence might affect behavior. Although this substitution was partially effective in our case, other CHANS researchers will want to consider what they might miss when using cross-sectional data to investigate CHANS relationships that evolve over longer time frames. Evaluating some actor behavior at the core of CHANS may require historical or retrospective studies, or longitudinal studies that track human responses to slow variables over time scales at which they operate.

The potential tyranny of complex quantitative models

We found that our project team's decision to make an ABM central to our research approach at the outset may have influenced both how individual social scientists were able to participate and what human system processes we examined. Complex quantitative models, such as ABMs, undoubtedly are useful for examining complex CHANS processes. However, the risk of undue focus on complex quantitative modeling is that the quantitative modeling itself will end up defining the direction of CHANS research, rather than vice versa. In our project, the structure and data demands of our ABM were the foci of early project meetings concerning how to coordinate and conduct our research. Several project social scientists felt unduly constrained by the analytical demands placed on them by the ABM and found 
it difficult to transfer the theoretical underpinnings of their own research to the ABM framework. The work of "feeding the model" occupied the time of several of the quantitative social and biophysical scientists on the team. This focus on getting the model up and running for our study area possibly came at the expense of conducting broader investigations about how our CHANS functioned, which might also have been informative. Additionally, selecting any given empirical model may sometimes necessitate excluding particular phenomena from investigation if those phenomena are not amenable to examination using a given model's structure or spatial or temporal scale of analysis. Examples of potentially relevant human system processes that we omitted include the possibility that wildfires propel political activity that operates as a feedback that influences future federal policy and management, and the possibility that severe wildfire activity spurs state or local land use planning policy changes that influence the pace and location of future housing development, and thus potentially influence the placement of future fuel reduction treatments by federal forest managers. Although the degree to which these processes might influence actor behavior relative to others in the CHANS we examined remains unknown, their potential effects on the landscape could be examined by representing them in the scenarios to be simulated.

Conducting interdisciplinary versus multidisciplinary research More broadly, we were challenged to fully integrate the work of the various disciplines represented on our project team. Our CHANS research proposal stressed that we would draw on both social and ecological disciplines to develop information about actor behavior that we would incorporate into an ABM, and we anticipated that our use of an ABM would facilitate our integration. However, we found that much of our work ultimately was more multidisciplinary, as individual social scientists on our project team largely "act[ed] within and preserv[ed] the exemplary concerns of their own discipline" (e.g., Roy et al. 2013:754) by developing data concerning the behavior of their selected actor group largely using the theories and methods of their respective disciplines. This self-selection in research task assignment influenced both which disciplines examined particular actor groups and which disciplines developed decision rules for the ABM. We found that our ABM enabled us to integrate information developed based on the theoretical and methodological backgrounds of the disparate disciplines represented on our project team (Shindler et al. 2017) but did not necessarily ensure that we developed integrated concepts and theories. Whether this affected our research outcomes is uncertain. Much of our initial social science effort was focused on developing a fundamental understanding of the CHANS in our fire-prone study area landscape, including identifying what actors were involved, what management activities they conduct, and what socioeconomic and biophysical factors influence them. Much of this process involved primary data collection and analysis, which was conducted mostly by those team members who possessed expertise in the methods that were best suited to evaluating particular actor groups. This focus may have limited our opportunities for developing theories that were more integrated across multiple disciplines, for example. However, by developing greater understanding of the human system components of fire-prone landscapes, our research has set the stage for further interdisciplinary developments in future work.

\section{CONCLUSIONS AND IMPLICATIONS FOR COUPLED HUMAN AND NATURAL SYSTEMS MODELING}

With growing policy interest in landscape-level social-ecological issues (e.g., Stine et al. 2014), researchers increasingly are called on to examine how people respond to their environment via their landscape management decisions and responses to fast and slow variables, both internal and external to CHANS. How well empirical models can contribute to that process depends in part on how well social and biophysical scientists can adequately represent human system dynamics in landscape-level models. Social science offers an array of theories and methods for examining and evaluating human actors and their behaviors. Our work exemplifies continuing challenges in conducting social science to represent actor behavior in empirical modeling. Papers that address interdisciplinary research often focus on conceptual, linguistic, perceptual, and philosophical differences among individual disciplines as barriers to discourse and collaboration (e.g., Turner and Carpenter 1999, Eigenbrode et al. 2007). To these challenges we might add the potential difficulties that arise from issues involving (1) data structure and its availability at spatial and temporal scales that are sufficient to examine socialecological phenomenon under study by different disciplines, and (2) whether it is analytically and technically feasible to fully integrate the work of different disciplines using empirical models, in part, given such data constraints. There may always be limits to what phenomena CHANS projects can study. However, improvement in CHANS research also may depend on individual CHANS projects recognizing and sharing their perspectives about their perceived limitations of individual projects so that future projects may better anticipate potential trouble spots ahead.

Based on our experiences in conducting our own CHANS research, including development and use of an ABM, we offer the following recommendations to the CHANS research community:

1. Convening research teams. When building CHANS research teams, project leaders should identify and consider prospective team members who are likely to best complement the knowledge, skills, and temperaments (e.g., Jakobsen et al. 2004, Lach 2014) of other prospective team members. Ideally, individual team members should possess sustained interest and capacity to work collaboratively rather than independently, be willing to engage different disciplines and consider new ways of viewing their own, and be willing to consider involving themselves in all aspects of the CHANS research effort rather than selecting only those portions with which they are most comfortable or interested. Project leaders also should consider the trade-offs in securing needed expertise versus enlisting a manageable number of team members. Although a portfolio approach to team formation may argue for including some redundancy to offset the possibility that some team members may not deliver, too much redundancy risks wasting project resources and time associated with negotiating and collaborating with a greater number of individuals, especially if some individuals are inappropriate for CHANS research. Reserving a portion of project funds for later securing unforeseen but needed expertise is a viable alternative. 
2. Qualitative versus quantitative methods. Although both qualitative and quantitative data and analyses can contribute to CHANS research (e.g., Lach 2014), projects that feature development and use of ABMs or other empirical models should include some social scientists who are comfortable and willing to work with quantitative data and analysis to ensure its transfer to the development and use of the empirical models involved. Alternatively, CHANS teams should identify individuals who are willing and able to act as intermediaries between more qualitative-minded team members and those individuals who are involved in development of empirical models. These roles should be anticipated and individuals should be identified at the outset, if possible. None of this, however, presumes that CHANS research necessarily must rely on empirical models and quantitative data, even though that has been a focus of our paper.

3. Reliance on existing models versus developing new models. CHANS research teams should consider potential advantages and disadvantages of committing to a specific or already established empirical model at the outset. The potential advantage of expediency and appeal during the grant proposal phase of committing to a particular empirical model may sometimes be outweighed by the potential constraints imposed on particular (e.g., social science) team members regarding what they will be able to contribute and what CHANS processes they might be able to address. Interdisciplinary projects must take care not to "minimize or compress" the content of one or another discipline "to amplify the content of another" (Wear 1999:301). We encourage CHANS projects to consider whether and how selecting a specific empirical model as a tool for facilitating integration may actually exclude particular disciplines or the examination of particular phenomena by virtue of the spatial and temporal scales at which the model may operate, for example, or other factors.

4. Defining project scope. Establishing bounds on what CHANS processes and influencing factors can be examined, at what temporal and spatial scales and scopes, is an unavoidable step. CHANS researchers should consider the criteria they will use to determine those bounds, and apply them thoughtfully and strategically. In some cases, resources (including time and funding) may necessitate that a project select approaches based more on expediency (e.g., we already have this empirical model available). In other cases, greater long-term knowledge may be generated when CHANS researchers also select methodologies and temporal and spatial scales of analysis that offer the most promising avenues for finding new and meaningful insights concerning social-ecological issues of interest. The selection of a subset of actor behaviors and influencing factors to include in CHANS empirical models is a milepost in the research process where researchers risk excluding phenomena and factors that may be critical to understanding the issue at hand. Even when researchers do recognize and select critical behaviors and influencing factors, it may not always be possible to integrate them into a select empirical model, given the data and analytical difficulties we highlight. Some CHANS interactions may not be amenable to evaluation using particular modeling approaches, such that the selection of a given approach involves trade-offs regarding what CHANS projects will be capable of learning. Examining some CHANS phenomenon may require longterm or iterative studies.

5. Fostering interdisciplinary engagement. Ideally, CHANS research should provide sufficient opportunities for different disciplines to inform each other (e.g., Wear 1999) by allowing adequate time for interdisciplinary cooperation and integration to develop (Jakobsen et al. 2004, Redman et al. 2004). Part of this involves coordinating analysis and modeling of human system with that of the natural system to ensure that key socioeconomic variables are adequately represented in biophysical models, and that key biophysical variables will be adequately represented in socioeconomic models. The typical 3- to 4-year research grant often may not provide enough time to fully develop complex integrated social-ecological systems models. Yet, it can be difficult to fund individual social or ecological research components in isolation if such work is not viewed as sufficiently novel or cross-disciplinary. Enabling CHANS research projects to plan beyond the typical 3- to 4-year research grant time horizon may be necessary to enable some projects to more fully develop. "Start-up" or "exploratory" funding at the grant proposal or early development stage could provide would-be CHANS projects with greater time and resources for pooling knowledge, considering research ideas, and developing conceptual frameworks and analytical approaches without the pressure to settle too early on a specific approach or empirical model merely to increase the likelihood of proposal selection, for example.

6. Post-project reflection and evaluation. Although the CHANS approach (e.g., Liu et al. 2007) provides an integrated conceptual framework for examining socialecological phenomena, many CHANS concepts - including feedbacks lagged in time and space via fast versus slow, and internal versus external variables, for example - are fairly abstract and offer little guidance to interdisciplinary teams on how to go about the task of evaluating human system conditions and processes, and their interactions with the natural system. For this reason, we feel that CHANS research, and interdisciplinary research more generally, could benefit from retrospective, candid self-reflection and documentation by individual research teams regarding the ways they feel their work may have both succeeded and failed at conducting CHANS research and in integrating the work of multiple disciplines involved. Such reporting not only would provide observations of different types of CHANS systems (e.g., Liu et al. 2007), it would provide retrospective observations and analyses about how CHANS research can be conducted, what challenges arise, and what solutions can be found. The future of CHANS research depends on developing clear examples of multidisciplinary and interdisciplinary CHANS research accomplishments, including evaluating the degree to which these characteristics may (or may not) influence what can be learned. We encourage other CHANS research teams to reflect on and document their own attempts at conducting CHANS research so that they might help guide future CHANS and interdisciplinary research efforts. 
Ideally, CHANS research would involve developing methods for conducting interdisciplinary analysis that enable multidisciplinary teams to examine the biophysical and social processes and influencing factors relevant to social-ecological issues at the temporal and spatial scales at which they operate. CHANS research teams should be encouraged to pursue a variety of approaches and methods - both quantitative and qualitative. CHANS research funding agencies and organizations could foster such diversity in the projects they fund. There likely are advantages and disadvantages to different approaches that manifest in different research contexts. Our research team's capacity and comfort in conducting multiple social science approaches can, in part, be traced to the diversity of social science disciplines represented on our team. We feel that this diversity positioned our team to secure project funding, investigate the major actors in our study area, and develop models for representing and evaluating landscape outcomes resulting from many of their behaviors. However, there likely are various paths that can be taken when conducting CHANS research. Choosing one path may have implications for what can or will be learned. A fundamental challenge for CHANS researchers may involve reflecting on the ways that our individual research decisions may influence what we learn (e.g., Shindler et al. 2017). Addressing that challenge likely calls for examining the CHANS research process itself.

Responses to this article can be read online at: http://www.ecologyandsociety.org/issues/responses. php/9329

\section{Acknowledgments:}

This research was funded by the National Science Foundation, Coupled Human and Natural Systems Program (NSF Grant CHH-1013296), the USDA Forest Service, Pacific Northwest Research Station, and the Interagency Joint Fire Sciences Program (Grants 09-1-08-31 and 14-1-01-22). We thank Keith Olsen for assistance with figures. We thank two anonymous reviewers for helpful comments.

\section{LITERATURE CITED}

Ager, A. A., M. A. Day, M. A. Finney, K. Vance-Borland, and N. M Vaillant. 2014. Analyzing the transmission of wildfire exposure on a fire-prone landscape in Oregon, USA. Forest Ecology and Management 334:337-390. http://dx.doi.org/10.1016/ j.foreco.2014.09.017

Ager, A. A., J. D. Kline, and A. P. Fischer. 2015. Coupling the biophysical and social dimensions of wildfire risk to improve wildfire mitigation planning. Risk Analysis 35(8):1393-1406. http://dx.doi.org/10.1111/risa.12373

An, L. 2012. Modeling human decisions in coupled human and natural systems: review of agent-based models. Ecological Modelling 229:25-36. http://dx.doi.org/10.1016/j.ecolmodel.2011.07.010

Anderies, J. M., M. A. Janssen, and E. Ostrom. 2004. A framework to analyze the robustness of social-ecological systems from an institutional perspective. Ecology and Society 9(1):18. http://dx. doi.org/10.5751/ES-00610-090118

Barros, A. M. G., A. A. Ager, M. A. Day, H. K. Preisler, T. A. Spies, E. M. White, R. J. Pabst, K. A. Olsen, E. Platt, J. D. Bailey, and J. P. Bolte. 2017. Spatiotemporal dynamics of simulated wildfire, forest management, and forest succession in central Oregon, USA. Ecology and Society 22(1):24. http://dx.doi. org/10.5751/ES-08917-220124

Barton, D. C., E. D. Eidson, D. A. Schoenwald, and K. L. Stamber. 2000. Aspen-EE: an agent-based model of infrastructure interdependency. Sandia National Laboratorie Report SAND2000-2925, Albuquerque, New Mexico, USA. http://dx.doi.org/10.2172/774027

Basu, N., R. Pryor, and T. Quint. 1998. ASPEN: a microsimulation model of the economy. Computational Economics 12:223-241. http://dx.doi.org/10.1023/A:1008691115079

Berkes, F., and C. Folke. 1994. Linking social and ecological systems for resilience and sustainability. Beijer Discussion Paper Series No. 52, Beijer International Institute of Ecological Economics, Royal Swedish Academy of Sciences, Stockholm, Sweden.

Brenkert-Smith, H., P. A. Champ, and N. Flores. 2006. Insights into wildfire mitigation decisions among wildland-urban interface residents. Society \& Natural Resources 19:759-768. http://dx.doi.org/10.1080/08941920600801207

Carpenter, S. R., H. A. Mooney, J. Agard, D. Capistrano, R. S. DeFries, S. Díaz, T. Dietz, A. K. Duraiappah, A. Oteng-Yeboah, H. M. Pereira, C. Perrings, W. V. Reid, J. Sarukhan, R. J. Scholes, and A. Whyte. 2009. Science for managing ecosystem services: beyond the Millennium Ecosystem Assessment. Proceedings of the National Academy of Sciences of the United States of America 106(5):1305-1312. http://dx.doi.org/10.1073/pnas.0808772106

Carpenter, S. R., and M. G. Turner. 2000. Hares and tortoises: interactions of fast and slow variables in ecosystems. Ecosystems 3(6):495-497. http://dx.doi.org/10.1007/s100210000043

Chapin, III, F. S., M. D. Robards, H. P. Huntington, J. F. Johnstone, S. F. Trainor, G. P. Kofinas, R. W. Ruess, N. Fresco, D. C. Natcher, and R. L. Naylor. 2006. Directional changes in ecological communities and social-ecological systems: a framework for prediction based on Alaskan examples. American Naturalist 168:S36-S49. http://dx.doi.org/10.2307/4122279

Charnley, S., T. A. Spies, A. M. G. Barros, E. M. White, and K. A. Olsen. 2017. Diversity in forest management to reduce wildfire losses: implications for resilience. Ecology and Society 22(1):22. http://dx.doi.org/10.5751/ES-08753-220122

Collins, S., and E. Larry. 2007. Caring for our natural assets: an ecosystem services perspective. U.S. Forest Service, Portland, Oregon, USA.

Daily, G. C., and P. R. Ehrlich. 1999. Managing the earth's ecosystems: an interdisciplinary challenge. Ecosystems 2:277280. http://dx.doi.org/10.1007/s100219900075

Donovan, G. H., J. P. Prestemon, and K. Gebert. 2011. The effect of newspaper coverage and political pressure on wildfire suppression costs. Society \& Natural Resources 24(8):785-798. http://dx.doi.org/10.1080/08941921003649482 
Eigenbrode, S. D., M. O'Rourke, J. D. Wulfhorst, D. M. Althoff, C. S. Goldberg, K. Merrill, W. Morse, M. Neilsen-Pincus, J. Stephens, L. Winowiecki, and N. A. Bosque-Perez. 2007. Employing philosophical dialogue in collaborative science. Bioscience 57(1):55-64. http://dx.doi.org/10.1641/B570109

Filatova, T., P. H. Verburg, D. C. Parker, and C. A. Stannard. 2013. Spatial agent-based models for socio-ecological systems: challenges and prospects. Environmental Modelling \& Software 45:1-7. http://dx.doi.org/10.1016/j.envsoft.2013.03.017

Fischer, A. P., A. Callahan, J. Koch, T. A. Spies, C. S. Olsen, E. M. White, and D. Jacobs. 2013a. Using the forest, people, fire agent-based social network model to investigate interactions in social-ecological systems. Practicing Anthropology 35(1):8-13. https://doi.org/10.17730/praa.35.1.w7348256k283t131

Fischer, A. P., and L. Jasny. 2017. Capacity to adapt to environmental change: evidence from a network of organizations concerned with increasing wildfire risk. Ecology and Society 22 (1):23. http://dx.doi.org/10.5751/ES-08867-220123

Fischer, A. P., J. D. Kline, A. A. Ager, S. Charnley, and K. A. Olsen. 2014. Objective and perceived wildfire risk and its influence on private forest landowners' fuel reduction activities in Oregon's (USA) ponderosa pine region. International Journal of Wildland Fire 23(1):143-153. http://dx.doi.org/10.1071/WF12164

Fischer, A. P., J. D. Kline, S. Charnley, and C. Olsen. $2013 b$. Erratum to 'Identifying policy target groups with qualitative and quantitative methods: the case of wildfire risk on nonindustrial private forest lands' [Forest Policy and Economics 25 (2012) 6271]. Forest Policy and Economics 28:69-78. http://www. sciencedirect.com/science/article/pii/S1389934113000294

Fischer, A. P., T. A. Spies, T. A. Steelman, C. Moseley, B. R. Johnson, J. D. Bailey, A. A. Ager, P. Bourgeron, S. Charnley, B. M. Collins, J. D. Kline, J. E. Leahy, J. S. Littell, J. D. A. Millington, M. Nielsen-Pincus, C. S. Olsen, T. B. Paveglio, Christopher I. Roos, M. M. Steen-Adams, F. R. Stevens, J. Vukomanovic, E. M. White, and D. M. J. S. Bowman. 2016a. Wildfire risk as a socioecological pathology. Frontiers in Ecology and the Environment 14(5):276-284. http://dx.doi.org/10.1002/fee.1283

Fischer, A. P., K. Vance-Borland, L. Jasny, K. E. Grimm, and S. Charnley. 2016b. A network approach to assessing social capacity for landscape planning: the case of fire-prone forests in Oregon, USA. Landscape and Urban Planning 147:18-27. http://dx.doi. org/10.1016/j.landurbplan.2015.10.006

Flick, U., editor. 2014. The Sage handbook of qualitative data analysis. Sage Publications, Los Angeles, California, USA. http:// dx.doi.org/10.4135/9781446282243

Folke, C. 2006. Resilience: the emergence of a perspective for social-ecological systems analyses. Global Environmental Change 16:253-267. http://dx.doi.org/10.1016/j.gloenvcha.2006.04.002

Folke, C., S. Carpenter, T. Elmqvist, L. Gunderson, C. S. Holling, and B. Walker. 2002. Resilience and sustainable development: building adaptive capacity in a world of transformations. Ambio 31(5):437-440. http://dx.doi.org/10.1579/0044-7447-31.5.437

Fox, H. E., C. Christian, J. C. Nordby, O. R. W. Pergams, G. D. Peterson, and C. R. Pyke. 2006. Perceived barriers to integrating social science and conservation. Conservation Biology 20(6):18171820. http://dx.doi.org/10.1111/j.1523-1739.2006.00598.x

Gunderson, L. H., and C. S. Holling, editors. 2001. Panarchy: understanding transformations in human and natural systems. Island Press, Washington, D.C., USA.

Hall, M. P. 2015. Remote detection and predicted locations of NIPF fuel treatments in central Oregon. Thesis. Oregon State University, Corvallis, Oregon, USA.

Happe, K., K. Kellerman, and A. Balmann. 2006. Agent-based analysis of agricultural policies: an illustration of the agricultural policy simulator AgriPoliS, its adaptation and behavior. Ecology and Society 11(1):49. http://dx.doi.org/10.5751/ES-01741-110149

Heemskerk, M., K. Wilson, and M. Pavao-Zuckerman. 2003. Conceptual models as tools for communication across disciplines. Conservation Ecology 7(3):8. http://dx.doi.org/10.5751/ES-00554-070308

Honghui, Z., Y. Yongnian, B. Ling, and Y. Xijun. 2010. Modelling urban expansion using a multi agent-based model in the city of Changsha. Journal of Geographical Sciences 20(4):540-556. http://dx.doi.org/10.1007/s11442-010-0540-Z

Jakobsen, C. H., T. Hels, and W. J. McLaughlin. 2004. Barriers and facilitators to integration among scientists in transdisciplinary landscape analysis: a cross-country comparison. Forest Policy and Economics 6:15-31. http://dx.doi.org/10.1016/S1389-9341(02) $\underline{00080-1}$

Janssen, M. A., and E. Ostrom. 2006. Empirically based, agentbased models. Ecology and Society 11(2):37. http://dx.doi. org/10.5751/ES-01861-110237

Klein, J. T. 1990. Interdisciplinarity: history, theory, and practice. Wayne State University Press, Detroit, Michigan, USA.

Kline, J. D., P. Thiers, C. P. Ozawa, J. A. Yeakley, and S. N. Gordon. 2014. How well has land-use planning worked under different governance regimes? A case study in the Portland, ORVancouver, WA metropolitan area, USA. Landscape and Urban Planning 131:51-63. http://dx.doi.org/10.1016/j.landurbplan.2014.07.013

Lach, D. 2014. Challenges of interdisciplinary research: reconciling qualitative and quantitative methods for understanding human-landscape systems. Environmental Management 52(1):8893. http://dx.doi.org/10.1007/s00267-013-0115-8

Lindell, M. K., and R. W. Perry. 2012. The protective action decision model: theoretical modifications and additional evidence. Risk Analysis 32(4):616-632. http://dx.doi.org/10.1111/ j.1539-6924.2011.01647.x

Liu, J., T. Dietz, S. R. Carpenter, M. Alberti, C. Folke, E. Moran, A. N. Pell, P. Deadman, T. Kratz, J. Lubchenco, E. Ostrom, Z. Ouyang, W. Provencher, C. L. Redman, S. H. Schneider, and W. W. Taylor. 2007. Complexity of coupled human and natural systems. Science 317(5844):1513-1516. http://dx.doi.org/10.1126/ science. 1144004

Metzger, N., and R. N. Zare. 1999. Interdisciplinary research: from belief to reality. Science 283(5402):642-643. http://dx.doi. org/10.1126/science.283.5402.642

Meyfroidt, P. 2012. Environmental cognitions, land change, and social-ecological feedbacks: an overview. Journal of Land Use Science 8:341-367. http://dx.doi.org/10.1080/1747423X.2012.667452 
Millington, J., R. Romero-Calcerrada, J. Wainwright, and G. Perry. 2008. An agent-based model of Mediterranean agricultural land-use/cover change for examining wildfire risk. Journal of Artificial Societies and Social Simulation 11(4):4. http://jasss.soc. surrey.ac.uk/11/4/4.html

Monticino, M., M. Acevedo, B. Callicott, T. Cogdill, and C. Lindquist. 2007. Coupled human and natural systems: a multiagent-based approach. Environmental Modelling \& Software 22:656-663. http://dx.doi.org/10.1016/j.envsoft.2005.12.017

Moritz, M. A., E. Batllori, R. A. Bradstock, A. M. Gill, J. Handmer, P. F. Hessburg, J. Leonard, S. McCaffrey, D. C. Odion, T. Schoennagel, and A. D. Syphard. 2014. Learning to coexist with wildfire. Nature 515:58-66. http://dx.doi.org/10.1038/ $\underline{\text { nature } 13946}$

Nagendra, H., and E. Ostrom. 2014. Applying the socialecological system framework to the diagnosis of urban lake commons in Bangalore, India. Ecology and Society 19(2):67. http://dx.doi.org/10.5751/ES-06582-190267

Olsen, C. S., J. D. Kline, A. A. Ager, K. A. Olsen, and K. C. Short. 2017. Examining the influence of biophysical conditions on wildland-urban interface homeowners' wildfire risk mitigation activities in fire-prone landscapes. Ecology and Society 22(1):21. http://dx.doi.org/10.5751/ES-09054-220121

Ostrom, E. 2007. A diagnostic approach for going beyond panaceas. Proceedings of the National Academy of Sciences of the United States of America 104(39):15181-15187. http://dx.doi. org/10.1073/pnas.0702288104

O’Sullivan, D., T. Evans, S. Manson, S. Metcalf, A. LigmannZielinska, and C. Bone. 2016. Strategic directions for agent-based modeling: avoiding the YAAWN syndrome. Journal of Land Use Science 11(2):177-187. http://dx.doi.org/10.1080/1747423X.2015.1030463

Parker, D. C., A. Hessl, and S. C. Davis. 2008. Complexity, landuse modeling, and the human dimension: fundamental challenges for mapping unknown outcome spaces. Geoforum 39:789-800. http://dx.doi.org/10.1016/j.geoforum.2007.05.005

Parker, D. C., S. M. Manson, M. A. Janssen, M. J. Hoffmann, and P. Deadman. 2003. Multi-agent systems for the simulation of land-use and land-cover change: a review. Annals of the Association of American Geographers 93:314-337. http://dx.doi. org/10.1111/1467-8306.9302004

Paton, D. 2003. Disaster preparedness: a social-cognitive perspective. Disaster Prevention and Management 12(3):210-216. http://dx.doi.org/10.1108/09653560310480686

Paveglio, T. B., and T. Prato. 2012. Integrating dynamic social systems into assessments of future wildfire losses: an experiential agent-based modeling approach. Pages 1-42 in H.C. Dupont, editor. Environmental management: systems, sustainability and current issues. Nova Science Publishers, Inc., Hauppauge, New York, USA.

Pickett, S. T. A., M. L. Cadenasso, and J. M. Grove. 2005. Biocomplexity in coupled natural-human systems: a multidimensional framework. Ecosystems 8(3):225-232. http:// dx.doi.org/10.1007/s10021-004-0098-7
Redman, C. L., J. M. Grove, and L. H. Kuby. 2004. Integrating social science into the Long-term Ecological Research (LTER) network: social dimensions of ecological change and ecological dimensions of social change. Ecosystems 7:161-171. http://dx. doi.org/10.1007/s10021-003-0215-Z

Rounsevell, M. D. A., D. T. Robinson, and D. Murray-Rust. 2012. From actors to agents in socio-ecological systems models. Philosophical Transactions of the Royal Society B 367(1586):259269. http://dx.doi.org/10.1098/rstb.2011.0187

Roy, E. D., A. T. Morzillo, F. Sijo, S. M. W. Reddy, J. M. Rhemtulla, J. C. Milder, T. Kuemmerle, and S. L. Martin. 2013. The elusive pursuit of interdisciplinarity at the humanenvironment interface. Bioscience 63(9):745-753.

Shindler, B., T. A. Spies, J. P. Bolte, and J. D. Kline. 2017. Integrating ecological and social knowledge: learning from CHANS research. Ecology and Society 22(1):26. http://dx.doi. org/10.5751/ES-08776-220126

Spies, T. A., E. White, A. Ager, J. D. Kline, J. P. Bolte, E. K. Platt, K. A. Olsen, R. J. Pabst, A. M. G. Barros, J. D. Bailey, S. Charnley, J. Koch, M. M. Steen-Adams, P. H. Singleton, J. Sulzman, C. Schwartz, and B. Csuti. 2017. Using an agent-based model to examine forest management outcomes in a fire-prone landscape in Oregon, USA. Ecology and Society 22(1):25. http://dx.doi. org/10.5751/ES-08841-220125

Spies, T. A., E. M. White, J. D. Kline, A. P. Fischer, A. A. Ager, J. Bailey, J. Bolte, J. Koch, E. Platt, C. S. Olsen, D. Jacobs, B. Shindler, M. M. Steen-Adams, and R. Hammer. 2014. Examining fire-prone forest landscapes as coupled human and natural systems. Ecology and Society 19(3):9. http://dx.doi.org/10.5751/ ES-06584-190309

Steelman, T. A. 2010. Implementing innovation: fostering enduring change in environmental and resource governance. Georgetown University Press, Washington, D.C., USA.

Steelman, T. A., and S. M. McCaffery. 2011. What is limiting more flexible fire management - public or agency pressure? Journal of Forestry.

Steen-Adams, M. M., S. Charnley, and M. D. Adams. 2017. Historical perspective on the influence of wildfire policy, law, and informal institutions on management and forest resilience in a multiownership, frequent-fire, coupled human and natural system in Oregon, USA. Ecology and Society 22(3):23. https://doi. org/10.5751/ES-09399-220323

Stine, P., P. Hessburg, T. Spies, M. Kramer, C. J. Fettig, A. Hansen, J. Lehmkuhl, K. O’Hara, K. Polivka, P. Singleton, S. Charnley, A. Merschel, and R. White. 2014. The ecology and management of moist mixed-conifer forests in eastern Oregon and Washington: a synthesis of the relevant biophysical science and implications for future land management. U.S. Forest Service General Technical Report PNW-GTR-897. http://dx.doi.org/10.2737/PNW-GTR-897

Tress, B., G. Tress, A. van der Valk, and G. Fry, editors. 2003. Interdisciplinary and transdisciplinary landscape studies: potential and limitations. Delta Series 2. WUR Alterra, Wageningen, Netherlands. 
Turner, M. G., and S. R. Carpenter. 1999. Tips and traps in interdisciplinary research. Ecosystems 2:275-276. http://dx.doi. org/10.1007/PL00010895

United States Forest Service (U.S. Forest Service). 2006. Cooperating across boundaries: partnerships to conserve open space in rural America. Washington, D.C., USA.

Walker, B. H., S. R. Carpenter, J. Rockstrom, A.-S. Crepin, and G. D. Peterson. 2012. Drivers, "slow" variables, "fast" variables, shocks, and resilience. Ecology and Society 17(3):30. http://dx.doi. org/10.5751/ES-05063-170330

Walters, C. 1986. Adaptive management of renewable resources. MacMillan Publishing Company, New York, New York, USA.

Wear, D. N. 1999. Challenges to interdisciplinary discourse. Ecosystems 2:299-301. http://dx.doi.org/10.1007/s100219900080

Zvoleff, A., and L. An. 2014. Analyzing human-landscape interactions: tools that integrate. Environmental Management 53:94-111. http://dx.doi.org/10.1007/s00267-012-0009-1 